\title{
Nykyaikaa etsimässä
}

\author{
Pekka Vartiainen: Postmoderni kirjallisuus. Länsimaisen kirjallisuuden historia 1945-2000. \\ Helsinki: BTJ Finland, 20I3. 960 s.
}

Pekka Vartiainen on tehnyt suururakan. Hänen vuonna 2009 julkaisemansa Länsimaisen kirjallisuuden historia kattoi kirjallisuushistorian antiikista 1900-luvun puoliväliin saakka, ja nyt ilmestynyt Postmoderni kirjallisuus jatkaa siitä mihin edellinen osa päättyi: vuodesta 1945 aina vuosituhannen vaihtumiseen. Kaksiosaisen historiakirjan ajallinen epäsymmetria mietityttää kuitenkin hiukan. Miksi rajapyykki on vedetty vuoteen 1945? Luontevampi kirjallisuushistoriallinen murroskohta olisi esimerkiksi 1700-luku, jolloin kehittyvät moderni romaanimuoto ja kritiikki-instituutio, sananvapaus ja journalismi, kustannustoiminta, tekijänoikeudet sekä kirjailijuus modernissa mielessä. Onko rajakohdan perustelu siinä, että maailma ei II maailmansodan jälkeen ollut enää entisensä?

Viimeisin vaihtoehto vaikuttaa todennäköisimmältä jo kirjan otsikon perusteella, sillä Vartiainen on nimennyt kirjallisuushistoriansa toisen osan Postmoderniksi kirjallisuudeksi. Miksi postmoderni, onhan taiteen yhteydessä aina puhuttu postmodernismista? Vaikka näitä käsitteitä käytetään usein synonyymisesti, tämä pieni terminologinen ero on itse asiassa merkittävä, minkä Vartiainen tuo hyvin kirjansa johdantoluvuissa esiin. Postmoderni tai paremminkin jälkimoderni on termi, joka kuvaa historiallista ja kulttuurista tilaa modernin jälkeen - maailmaa, jota luonnehtivat globalisaatio, postkolonialismi, informaatioteknologian ja kuluttamisen muuttuminen osaksi maailmassa olemistamme, sekä kulttuurin suhteellistuminen ja tuotteistuminen. Postmodernismi puolestaan viittaa tätä jälkimodernin ajan kokemusta kuvaavaan taiteeseen. Kirjallisuudentutkimuksessa postmodernismi on myös nimi uudenlaiselle kirjalliselle suuntaukselle, jonka ensimmäiset tunnetut teokset syntyivät 1960-luvulla ja jonka päättymisestä vasta kiistellään.

Vartiaisen ratkaisu terminologiakysymykseen on historioitsijan, ei teoreetikon: hän kutsuu käsittelemäänsä 55 vuoden jaksoa postmoderniksi juuri kulttuurihistoriallisin perustein. Vain murto-osa teoksessa mainituista sadoista teoksista tai kirjailijoista edustaa postmodernismia esteettisessä mielessä. Siihen nähden, että postmoderni-termi on saanut näin näkyvän aseman kirjassa, on kuitenkin paha puute, että lähdeluettelosta ei juuri löydy postmodernia tai postmodernismia käsitteleviä alkuperäistekstejä sen paremmin kirjallisuuden- kuin kulttuurintutkimuksenkaan puolelta. (Poikkeuksen muodostavat ainoastaan Brian McHale ja Ihab Hassan, joilta kummaltakin on mainittu yksi teos.) Kirjallisen postmodernismin käsittely jää näin pakostakin väljän yleiselle tasolle, 
eikä mitään mainittavaa liittoa myöhemmissä luvuissa käsiteltyjen teosten kanssa synny. Muutenkin kirjan lähdeluettelo on historiatutkimuksen osalta kovin lyhyt, sanoisin jopa huolestuttavan lyhyt miltei tuhatsivuiselle opukselle, joka on ensimmäinen suomenkielinen yleisesitys oman aikamme kirjallisuushistoriasta. On ilmeistä, että kirjan painopiste on mahdollisimman kattavassa kirjallisuuden ja kirjallisen kentän kuvailussa, ei suurissa linjanvedoissa.

Vartiainen on hyvin selvillä kirjallisuushistorian kirjoittamiseen liittyvistä ongelmista, kuten siitä, että se sisältää väistämättä poistoja ja rajauksia. Tässä tapauksessa se tarkoittaa keskittymistä miltei yksinomaan proosan ja painetun kirjallisuuden historiaan, vaikka 1980luvulta lähtien voimistunut kirjallisuuden digitalisoituminen on muokannut radikaalisti lukemista ja kirjoittamista sekä lisännyt kirjallisuuden sulautumista muihin taiteisiin ja esittämisen muotoihin.

Vartiainen korostaa omaa kirjallisuushistoriaansa tarinana. Näin hän tulee liittyneeksi 1800- ja 1900-lukujen suurten kirjallisuushistorioiden traditioon ja havainnollistaneeksi sitä mitä David Perkins kutsuu kirjassaan Is Literary History Possible (1992) narratiiviseksi kirjallisuushistoriaksi. Narratiivinen historiankirjoitus korostaa teosten kohdalla suurempaa tarinaa, johon teokset kuuluvat - kehityskulkuja, alkuja ja päätepisteitä. Narratiivinen kirjallisuushistoria on hyvin suosittua siksi, että se tarjoaa helpon lähestymistavan historiallisiin prosesseihin. Siinä on Perkinsin mukaan kuitenkin myös omat ongelmansa, kuten determinismi, historiallisten katkosten ohittaminen, koherenssin ylikorostaminen sekä kirjallisten teosten esteettisen erityisyyden ja niiden välisten laatuerojen sivuuttaminen. Joitakin näistä piirteistä on havaittavissa myös Vartiaisella, kuten esimerkiksi globalisaation kuvaaminen yksinomaan hyväksi asiaksi sekä nykykirjallisuuden kentän heterogeenisyyden toistuva yhdenmukaistaminen jonkin periaatteen tai ilmiön nojalla (kuten esimerkiksi luvussa "Kirjallisuuden maailma on yksi").

Parhaimmillaan Vartiaisen teksti on sujuvaa ja hän osaa kontekstualisoida käsittelemänsä kirjallisuuden suhteessa tiettyyn kielialueeseen, kulttuuriin ja historialliseen tilanteeseen. Lisäksi hän tulee tunnettujen kirjailijoiden lisäksi käsitelleeksi suuren joukon jo unohdettuja tai meillä aivan tuntemattomia nimiä. Näkökulma on toki eurooppalainen: Amerikkaa lukuun ottamatta muiden maanosien kirjallisuutta ei käsitellä kuin ohimennen, mikä on tietysti yksi tekijän tietoisista rajauksista.

Kirjan miinuspuolena on epämääräinen kielenkäyttö, josta puuttuu analyyttistä tarkkuutta. En tietenkään peräänkuuluta tieteellisen jargonin lisäämistä yleistajuiseksi tarkoitettuun teokseen, mutta jäin kaipaamaan omien näkökulmien selkeää esiin tuomista sekä rohkeampia tulkintoja käsitellyistä teoksista. Kirjan kieliasussa on lisäksi joitakin 
outouksia, kuten lukemista ajoittain haittaava pilkutus, ymmärrettävyyttä hankaloittava metaforien ketjuttaminen ("aatteellinen selkäranka tukeutuu mystiikkaan") sekä esimerkiksi "katsanto"-sanan käyttäminen vähän latistavana teorian synonyyminä. Puutteistaan huolimatta kirja on hyvä ja tarpeellinen kirjallisuushistorian yleisesitys, jonka nimenä olisi voinut olla ihan perustellusti sen nykyinen alaotsikko, Länsimaisen kirjallisuuden historia 1945-2000.

\section{Kirjoittaja}

Tiina Käkelä-Puumala, FT, Helsingin yliopisto, yleinen kirjallisuustiede (tkakela[at]mappi.helsinki.fi)

Joutsen / Svanen 20I4. ISSN 2342-2459

www.helsinki.fi/kirjallisuuspankki/joutsen-svanen-20/4 